\title{
THE INFLUENCE OF SAVANNAH RIVER DISCHARGE AND CHANGING SRS COOLING WATER REQUIREMENTS ON THE POTENTIAL ENTRAINMENT OF ICHTHYOPLANKTON AT THE SRS SAVANNAH RIVER INTAKES (U)
}

by M. H. Paller

Westinghouse Savannah River Company

Savannah River Site

Aiken, South Carolina 29808

WSRC-RP--92-1001

Other Authors:

This paper was prepared in connection with work done under Contract No. DE-AC09-89SR18035 with the U.S. Department of Energy. By acceptance of this paper, the publisher and/or recipient acknowledges the U.S. Government's right to retain a nonexclusive, royalty-free license in and to any copyright covering this paper, along with the right to reproduce and to authorize others to reproduce all or part of the copyrighted paper. 


\section{DISCLAIMER}

This report was prepared as an account of work sponsored by an agency of the United States Government. Neither the United States Government nor any agency thereof, nor any of their employees, makes any warranty, express or implied, or assumes any legal liability or responsibility for the accuracy, completeness, or usefulness of any information, apparatus, product, or process disclosed, or represents that its use would not infringe privately owned rights. Reference herein to any specific commercial product, process, or service by trade name, trademark, manufacturer, or otherwise does not necessarily constitute or imply its endorsement, recommendation, or favoring by the United States Government or any agency thereof. The views and cpinions of authors expressed herein do not necessarily state or reflect those of the United States Government or any agency thereof.

This report has been reproduced directly from the best available copy.

Available to DOE and DOE contractors from the Office of Scientific and Technical Information, P. O. Box 62, Oak Ridge, TN 37831; prices available from (615) $576-8401$.

Available to the public from the National Technical Information Service, U. S. Department of Commerce, 5285 Port Royal Rd., Springfield, VA 22161. 
WSRC-RP-92-1001

Rev 0

D. B. Moore-Shedrow, Manager

Authorized Derivative Classifier

THE INFLUENCE OF SAVANNAH RIVER DISCHARGE AND CHANGING SRS COOLING WATER REQUIREMENTS ON THE POTENTIAL ENTRAINMENT OF ICHTHYOPLANKTON AT THE SRS SAVANNAH RIVER INTAKES (U)

by

M. H. Paller

SAVANNAH RIVER TECHNOLOGY CENTER

APPROVED BY: $\quad \frac{2 x}{\text { D. B. Moore-Shedrow, Manager }}$

Environmental Sciences Section

AUGUST 1992

Westinghouse Savannah River Company

Savannah River Site

Aiken, SC 29808

THIS DOCUMENT WAS PREPARED IN CONNECTION WITH WORK UNDER THE U.S. DEPARTMENT OF ENERGY (CONTRACT DE-AC09-89SR18035). 


\begin{abstract}
Entrainment (i.e., withdrawal of Eish larvae and eggs in cooling water) at the SRS Savannah River intakes is greatest when periods of high river water usage coincide with low river discharge during the spawning season. American shad and striped bass are the two species of greatest concern because of their recreational and/or commercial importance and because they produce drifting eggs and larvae vulnerable to entrainment. In the mid-reaches of the Savannah River, American shad and striped bass spawn primarily during April and May. An analysis of Savannah River discharge during April and May 1973-1989 indicated the potential for entrainment of 4-18z of the American shad and striped bass larvae and eggs that drifted past the SRS. Average April and May entrainment rates would have consistently exceeded 128 during the low water years of 1985-1989. This analysis assumed the concurrent operation of $\mathrm{L}-, \mathrm{K}-$, and $\mathrm{P}$-Reactors. Additional scenarios investigated were: 1) shutting down Land P-Reactors, maintaining minimum flows to Steel Creek (required to protect aquatic habitat), and operating $\mathrm{K}-$ Reactor with a recycle cooling tower; and 2) shutting down L- and P-Reactors, eliminating minimum flows to steel Creek, and operating $K$-Reactor with a recycle cooling tower. The former scenario reduced potential entrainment to $0.7-3.3 z$, and the latter scenario reduced potential entrainment to 0.2 $0.8 \%$. Thus, the currently favored scenario of operating $K-$ Reactor with a cooling tower and not operating $L-$ and $P-$ Reactors represents a significant lessening of the impact of SRS operations. Entrainment can be further reduced by reducing the minimum flow requirements to Steel Creek.
\end{abstract}


INTRODUCTION

Cooling water for Savannah River Site (SRS) reactors and makeup water for Par Pond is pumped from the Savannah River at the $1 G$ and $3 G$ pumphouses (Figure 1 ).

Ichthyoplankton (drifting fish larvae and eggs) from the river are entrained with the river water and passed through the reactor heat exchangers where temperatures may reach $70^{\circ} \mathrm{C}$ (Halverson et al. 1987) during full power operation.

Ichthyoplankton mortality under such conditions is assumed to be $100 \%$. The amount of ichthyoplankton entrained into the reactor cooling systems depends on the density and distribution of ichthyoplankton in the river, river discharge levels, and the volume of water withdrawn for cooling.

Savannah River discharge in the vicinity of the SRS (approximately RM $130-160$ ) is largely determined by the release of water from J. Strom Thurmond Reservoir, an Army Corp of Engineers mainstream impoundment located at RM 237.7 . During droughts, such as the one that occurred in late 1987 and in 1988, discharge from Lake Thurmond is very low resulting in low flows near the SRS. Under such conditions, the SRS is capable of removing a greater proportion of the river discharge and, therefore, a greater proportion of the ichthyoplankton drifting past the SRS. The greatest entrainment losses occur when periods of low flow are concurrent with periods of peak ichthyoplankton abundance.

The amount of cooling water needed for SRS operations is determined by the number of reactors in operation and by the operational mode of the reactors. During former times, the concurrent operation of $\mathrm{L}-, \mathrm{K}-$, and $\mathrm{P}$-Reactors resulted in a total cooling water requirement of approximately 2.3 .7 cubic meters per second (cms). Shutdown of $\mathrm{L}$ - and $\mathrm{P}$-Reactors and conversion of the $\mathrm{K}$-Reactor once-through cooling system to a recycle cooling system (upon completion of the $\mathrm{K}$-cooling tower and tie in with $k$-Reactor) will reduce this quantity to approximately 2.6-4.1 cms. This quantity consists of approximately $1.1 \mathrm{cms}$ for $\mathrm{K}$-cooling tower operation and and $1.5-3.0 \mathrm{cms}$ for the maintenance of fish habitat in steel creek. Three cris is provided during March through June to maintain spawning and nursery areas, and $1.5 \mathrm{cms}$ is provided during the rest of the year.

Only fish that produce drifting eggs and larvae are likely to be impacted by entrainment. Most of the drifting eggs and larvae in the Savannah River are produced by two anadromous species, American shad (Alosa sapidissima) and striped bass (Morene saxatilis) (Paller et al. 1984, Paller et al 1985, Paller et al 1986). Both species are of high commercial and/or recreational value. The striped bass, in particular, is a highly esteemed sport fish. Because striped 
bass reproduction is decreasing in the tidal Savannah River, interest in mid Savannah River striped bass stocks is currently increasing ( $M$. Van Den Avyle, personal communication). Current efforts to improve American shad populations in the Savannah River has generated considerable interest in this species as well.

The objectives of this report are to:

1) investigate the relationship between Savannah River discharge and the entrainment of American shad and striped bass at the SRS Savannah kiver intakes with special reference to the low flow conditions that existed during 1985 - 1989 .

2) investigate the effects of declining cooling water requirements on the entrainment of striped bass and American shad at the SRS Savannan intakes.

\section{SAVANNAH RIVER DISCHARGE LEVELS}

The United States Geological Survey (USGS) maintains several gaging stations on the Savannah River. The Jackson Gaging station (RM 156.8) is closest to the SRS intake canals (RMs 157.3 and 155.4 ) and provides the best measure of water flow past the intake canals. However, Savannah River discharges exceeding 616 cms (cubic meters per second) [22000 cfs(cubic feet per second)] cannot be accurately measured at the Jackson Gaging Station. Such flows inundate the broad Savannah River floodplain and are not tightly coupled with river stage. In this report, flows too high to measure were assumed to equal $616 \mathrm{cms}$, thus providing a conservatively low estimate of Savannah River discharge during high flow periods.

Figure 2 depicts yearly average and minimum discharges at the Jackson Gaging Station during 1973 - 1989. Minima are the lowest daily values recorded during each year. Average and, to a lesser extent, minimum discharges exhibit a general trend of decrease during 1973 - 1989. Particularly low flows occurred during 1981 - 1982 and during 1985 - 1989. Minimum yearly discharges were approximately 20 to $160 \mathrm{cms}$ less than average yearly discharges; the largest differences occurred during high discharge years.

Figure 3 depicts average monthly, minimum monthly, and minimum daily discharges at the Jackson Gaging Station during 1973 - 1989. The minimum monthly discharge for each month is the lowest average monthly discharge observed for the month. The minimum daily discharge for each month is the lowest average daily discharge observed for the month. Minimum daily and minimum monthly discharges exhibited less seasonal change than average monthly discharges (Figure 2). The coefficients of variation for minimum daily and minimum 
monthly discharges were 10.0 and 9.6 , respectively, in contrast to 23.9 for the average monthly discharge. Minimum daily flows are only slightly (average of $14.4 \%$ ) lower than minimum monthly flows. The period of highest flow in the Savannah River extends from February through April.

\section{TEMPORAL TRENDS IN AMERICAN SHAD AND STRIPED BASS ICHTHYOPLANKTON ABUNDANCE}

American shad and striped bass ichthyoplankton were collected from the Savannah River on a weekly basis from February - July during 1982, 1983, 1984, and 1985 (ECS 1983, Paller et al. 1984, Paller et al 1985, Paller et al 1986) as part of an effort to assess the impacts of SRS operations on Savannah River fisheries resources. Ichthyoplankton were collected from a number of locations, including RM 155.4 and RM 157.3 which are located just upstream from the $1 G$ and $3 G$ intake canals, respectively. Over $90 \%$ of the ichthyoplankton of both species consisted of eggs rather than larvae.

Median monthly densities of American shad and striped bass ichthyoplankton at RMs 155.4 and 157.3 are shown in Figures 4 and 5, respectively. American shad densities peaked in April and May; relatively low densities were observed in March and June, and virtually no American shad were collected in other months. Striped bass densities peaked in May; relatively low densities were observed in April and no striped bass were collected in the remaining months. These data demonstrate that April and May are the months of maximum potential entrainment of American shad and striped bass ichthyoplankton at the SRS Savannah River water intakes.

\section{RELATIONSHIP BETWEEN SAVANNAH RIVER DISCHARGE, COOLING WATER NEEDS AND PERCENT WATER WITHDRAWAL}

Entrainment impacts at the SRS intakes are dependent upon the proportion of Savannah River water withdrawn during the period of ichthyoplankton occurrence. The proportion of Savannah River water withdrawn is dependent upon SRS water requirements in relation to Savannah River discharge levels. Three SRS water requirements were investigated in the following analysis:

1) $23.7 \mathrm{cms}$, the approximate amount of water required to operate $\mathrm{K}$-Reactor and L-Reactor at full power in a once through cooling mode (approximately $11.2 \mathrm{cms}$ each) and supply Par Pond with make-up water during the operation of P-Reactor (approximately $1.3 \mathrm{cms}$ ), 
2) $4.1 \mathrm{cms}$, the approximate amount of water required to operate $\mathrm{K}$-Reactor in a recycle cooling mode and meet the steel Creek flow requirements,

3) $1.1 \mathrm{cms}$, the approximate amount of water required to operate $\mathrm{k}$-Reactor with a recycle cooling tower.

Water requirement 1 prevailed in the past, water requirement 2 will prevail in the future upon completion of the $\mathrm{K}$-cooling tower, and water requirement 3 is possible if minimum flow requirements for Steel Creek are renegotiated." The analysis includes only the months of April and May since striped bass and American shad ichthyoplankton are comparatively rare or absent at other times.

Figure 6 depicts the frequency of occurrence of different Savannah River discharge levels during April and May based on records taken from the Jackson gaging station during 1973 - 1989. It also depicts the percentage of river water that would be withdrawn at the SRS intakes (1G and 3G canals) at each Savannah River discharge level assuming water withdrawals of $23.7,4.1$, and $1.1 \mathrm{cms}$. Average monthly values rather than average daily values were used to construct Figure 6 . The frequency of low average monthly discharges indicates the potential for prolonged periods of high withdrawal which are likely to have more serious impacts than short (i.e., daily) periods of high withdrawal. The use of average daily rather than average monthly discharges in Figure 6 would only have increased maximum withdrawal rates by a smald proportion (from $16 \%$ to $18 \%$ in April and from $18 \%$ to 198 in May) due to the relatively small difference ketween minimum monthly discharges and minimum daily discharges (Eigure 3).

Average monthly Savannah River üischarges ranged from $153 \mathrm{cms}$ to $572 \mathrm{cms}$ in April and from $132 \mathrm{cms}$ to $397 \mathrm{cms}$ in May. The high values in the preceding ranges underestimate actual discharge levels because of the use of a conservative value to epresent discharges in excess of $616 \mathrm{cms}$. Discharge was generally higher in April than in May as indicated by a comparison of the grand mean discharge for each month (349 cms in April and $251 \mathrm{cms}$ in May). The maximum percentage of the Savannah River discharge that would be withdrawn at the SRS intakes at a water usage rate of 23.7 cms is $16 \%$ in April and $18 \%$ in May Eigure 6). Relatively high withdrawals $(\geq 12 z)$ occurred when average monthly discharges were below $200 \mathrm{cms}$. Average discharges below 200 cms were observed during 5 out of the 17 years (29\%) in April and during 7 out of the 17 years (418) in May. Average April and May discharges below $200 \mathrm{cms}$ occurred consistently during the low rainfall years of 1985 - 1989 (Figure 6). Average withdrawals during all 17 years included in the andysis were approximately 8.48 in April and 10.98 in May. Note that the preceding percent withdrawal rates are also equal to percent 
entrainment rates assuming that the larvae and eggs are homogeneously distributed vertically and horizontally near the intake canals.

Reduction of SRS water requirements to $4.1 \mathrm{cms}$ by shutting down $L-$ and $P$-Reactors, operating K-Reactor with a recycle cooling tower, and maintaining minimum flow requirements to Steel Creek decreased percentage withdrawals to a maximum of $2.7 \%$ in April and 3.3\% in May. Average withdrawals for all 17 years assuming a water requirement of $4.1 \mathrm{cms}$ were $1.5 \%$ in April and $1.9 \%$ in May. Further reduction of Savannah River water withdrawals to $1.1 \mathrm{cms}$ by eliminating Steel Creek flow requirements reduced the withdrawal percentage to a maximum of approximately $0.7 q$ in April and 0.88 in May. Average withdrawals for all 17 years assuming a water requirement of $1.1 \mathrm{cms}$ were approximately $0.4 \%$ in April and $0.5 \%$ in May.

Understanding the relationship between SRS water requirements, Savannah River discharge, and percent withdrawal permits entrainment to be estimated but does not provide a complete understanding of entrainment impacts in American shad and striped bass stocks because population level impacts are influenced by a variety of factors. However, it is obvious that any mitigation measure that reduces entrainment is likely to make the continued operation of the SRS water intakes more acceptable from an environmental perspective. The currently favored scenario of operating K-Reactor with a cooling tower and not operating Land P-Reactors reduces entrainment far below previous levels and represents a significant lessening of the impact of SRS operations. Entrainment can be further reduced by eliminating the minimum flow requirements to Steel Creek. The latter step would necessitate a predictive assessment of the impacts of reduced flows on aquatic organisms in steel Creek and, if warranted by the results of the predictive assessment, renesotiation of the 1984 agreement between DOE and SCDHEC.

\section{REFERENCES}

DOE (Department of Energy). 1984. Preliminary Predictive 316 (a) for L Lake. Submitted to the South Carolina Department of Health and Environmental Control. Savannah River Operations office, Aiken, SC.

ECS (Environmental and Chemical Sciences, Inc.). 1983. Final Report on the Preliminary Biological Measurement Program in the Savannah River. 1 March through 31 August, 1982. ECS-SR-2 (DPST-83-439), prepared by Environmental \& Chemical sciences, Inc. for E. I. du Pont de Nemours and Company, Savannah River Plant, Aiken, South Carolina. 
Halverson, N.V., J.B. Gladden, M.W. Lower, H.E. Mackey, W.L. Specht, and E.W. Wilde. 1987. Comprehensive Cooling Water Study Final Report, Volume I, Summary of Environmental

Effects. Dp-1739-1. E. I. du Pont de Nemours and Company, Savannah River Plant, Aiken, South Carolina.

Paller, M.H., J. O'Hara, D.V. Osteen, W. Specht, and H. Kania. 1984. Annual Report on the Savannah River Aquatic Ecology Program, September 1982 - August 1983, Volume I. ECS-SR-8 (DPST-84-252), prepared by Environmental \& Chemical Sciences, Inc. for E. I. du Pont de Nemours and Company, Savannah River Plant, Aiken, South Carolina.

Paller, M.H., J. O'Hara, and D.V. Osteen. 1985. Annual report on the Savannah River Aquatic Ecology Program, September 1983 - August 1984, Volume II, Ichthyoplankton. ECS-SR-18, prepared by Environmental \& Chemical Sciences, Inc. for $E$. I. du Pont de Nemours and Company, Savannah River Plant, Aiken, South Carolina.

Paller, M.H., B.M. Saul, and D.V. O: teen. 1986. Distribution and abundance of ichthyoplankton in the midreaches of the Savannah River and selected tributaries. ECSSR-27, prepared by Environmental \& Chemical Sciences, Inc. for E. I. du Pont de Nemours and Company, Savannah River Plant, Aiken, South Carolina. 


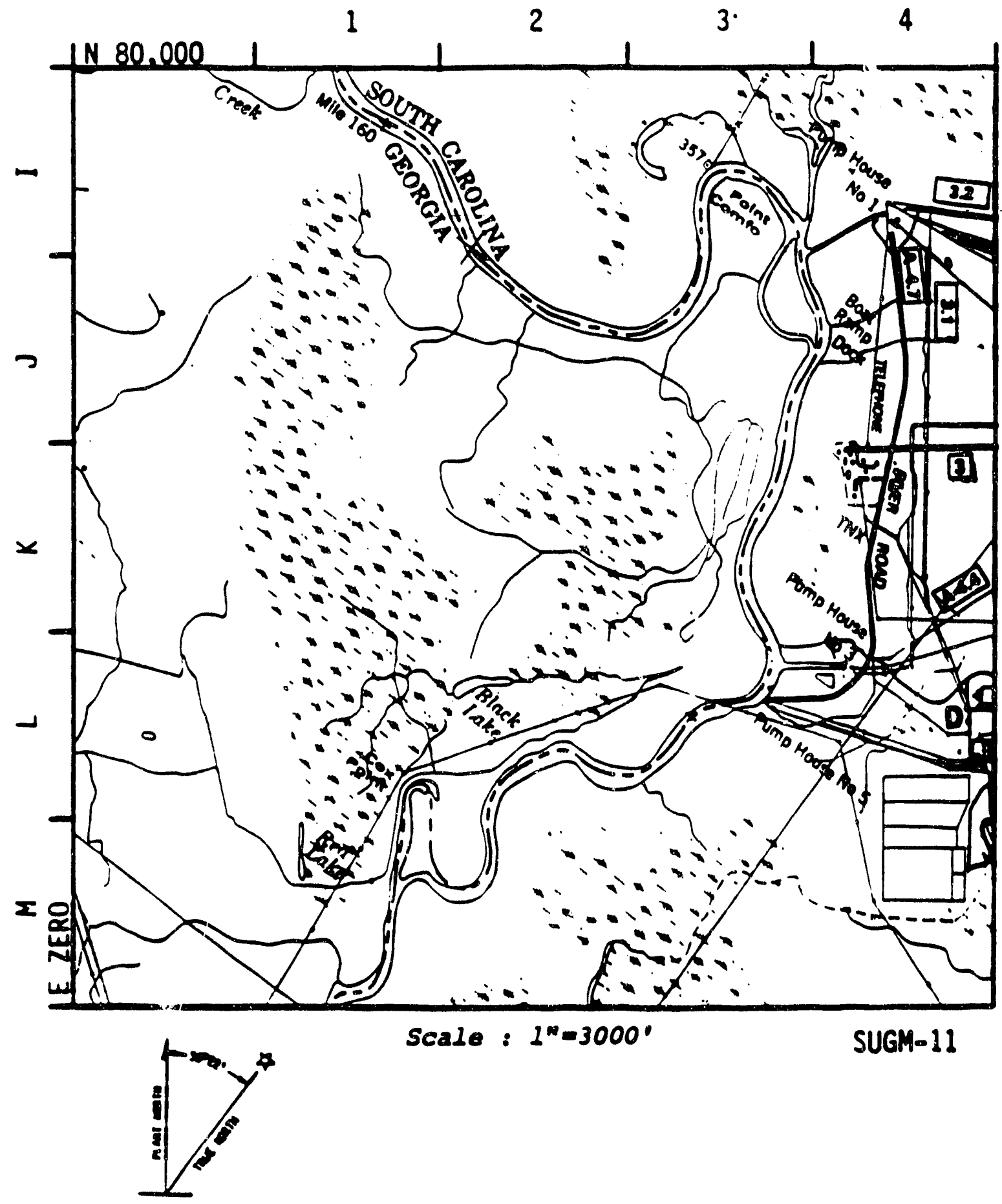

Eigure 1. Map of the Savannah River Site (SRS) showing the location of the pump house intakes on the Savannah River. 


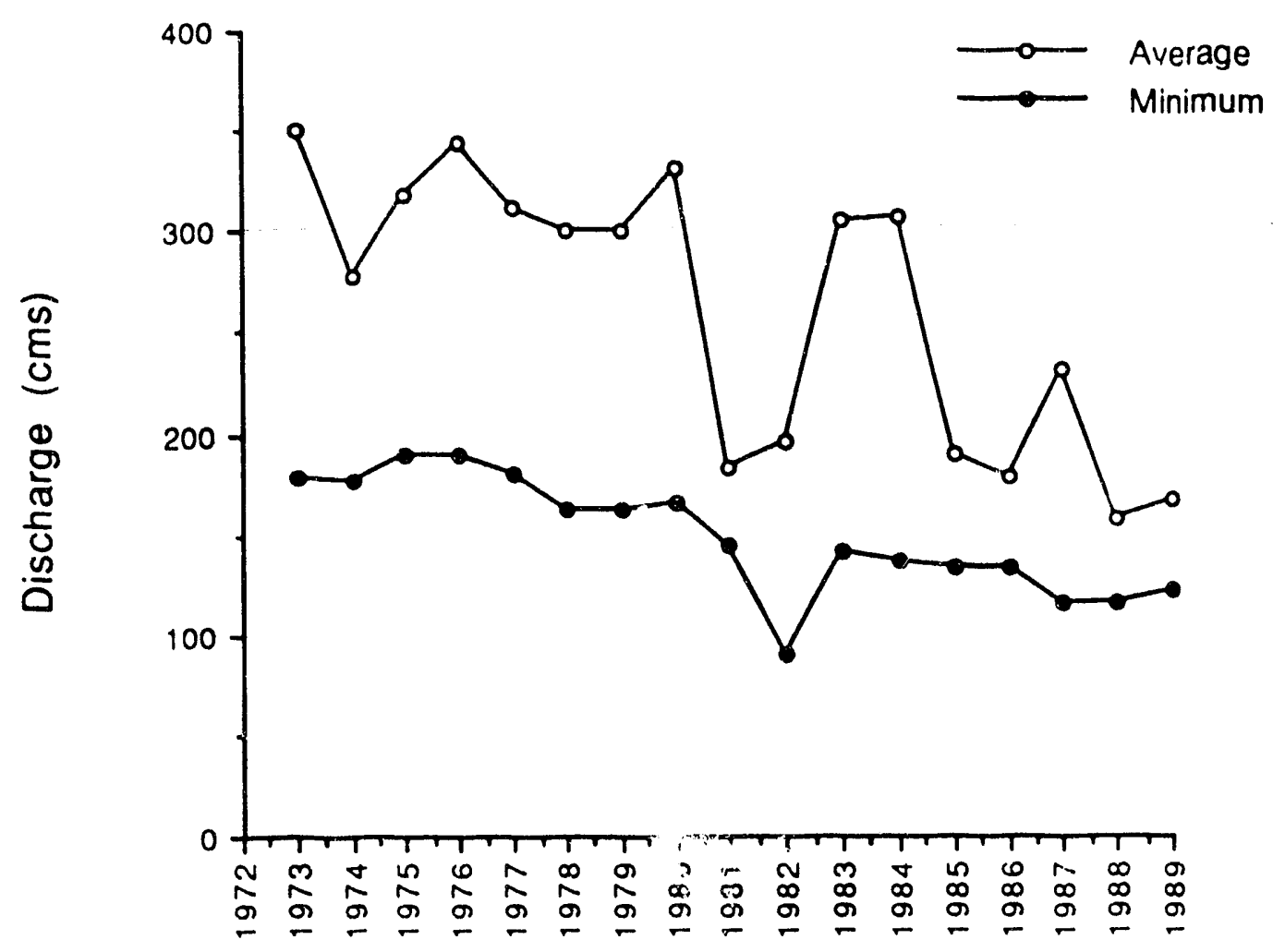

Figure 2. Average yearly and minimum daily flows in the Savannah River near the Jackson gaging station (RM $156.8)$ during 1973 - 1989. 


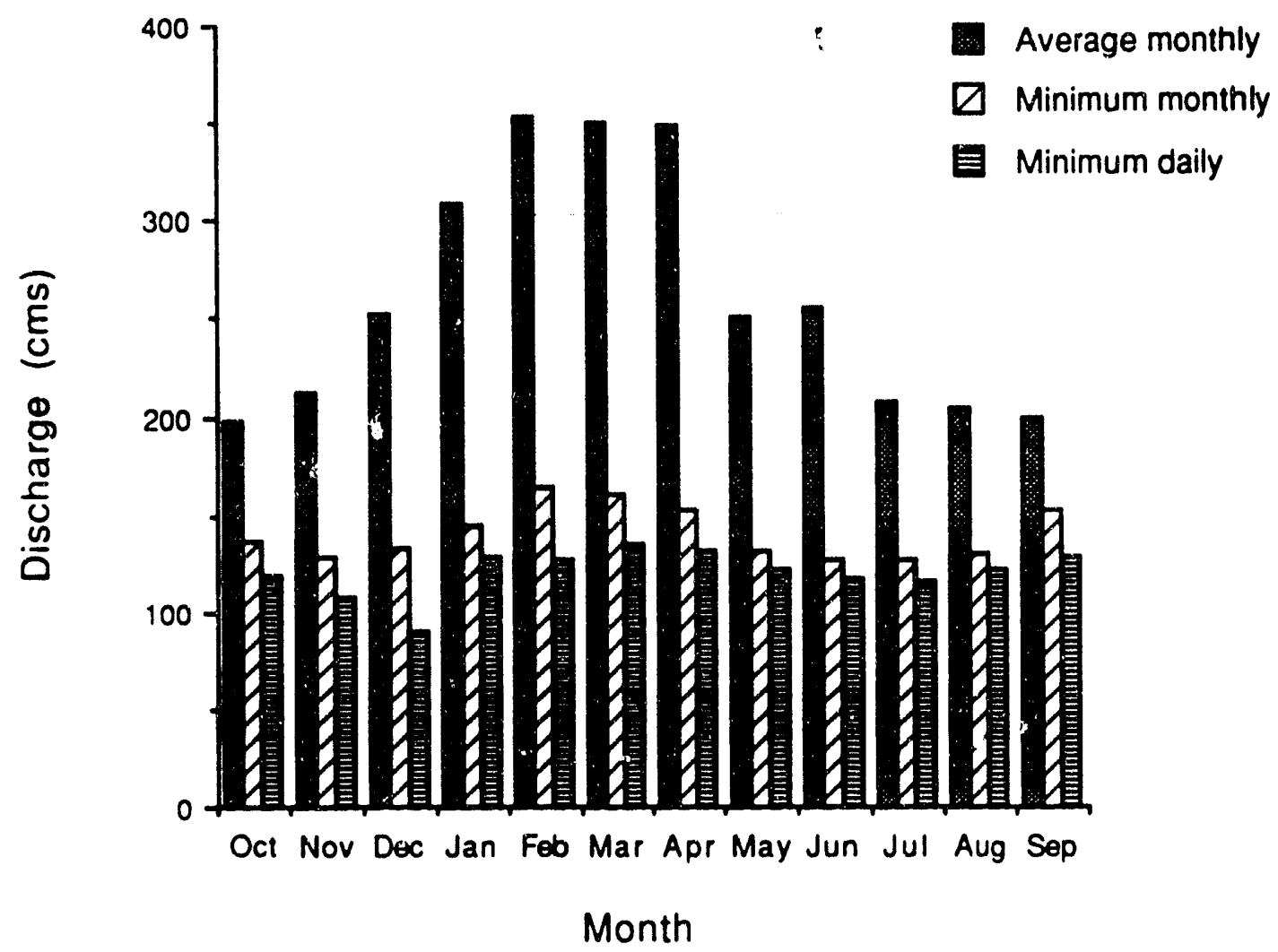

Figure $\vdots$. Average monthly, minimum monthly, and minimum daily discharges in the Savannah River near the Jackson gaging station (RM 156.8) during 1973 1989. 


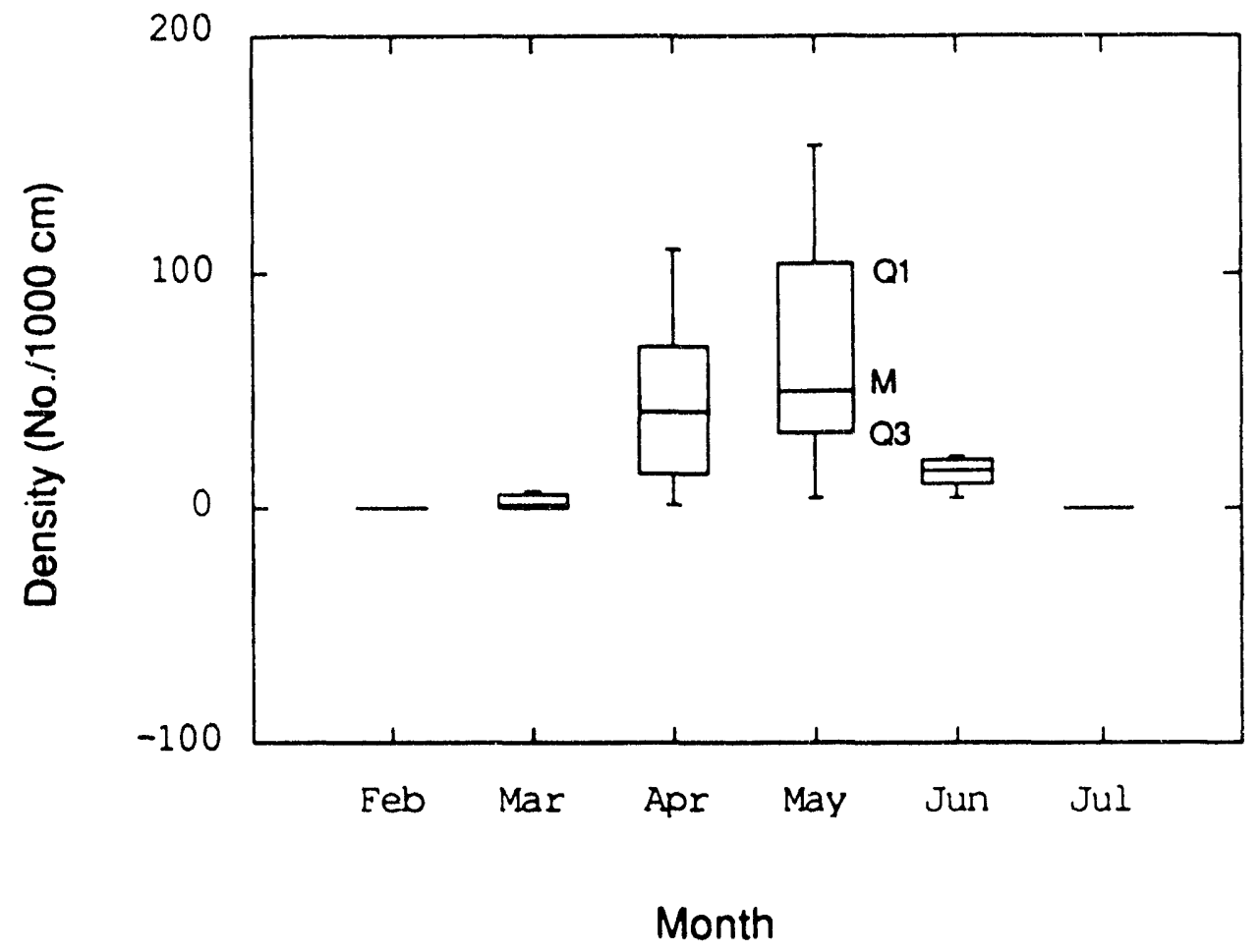

Figure 4. Box plot showing monthly median (M), first quartile (Q1), third quartile (03), and range of American shad ichthyoplankton densities (number/1000 cubic meters) during 1982 - 1985. 


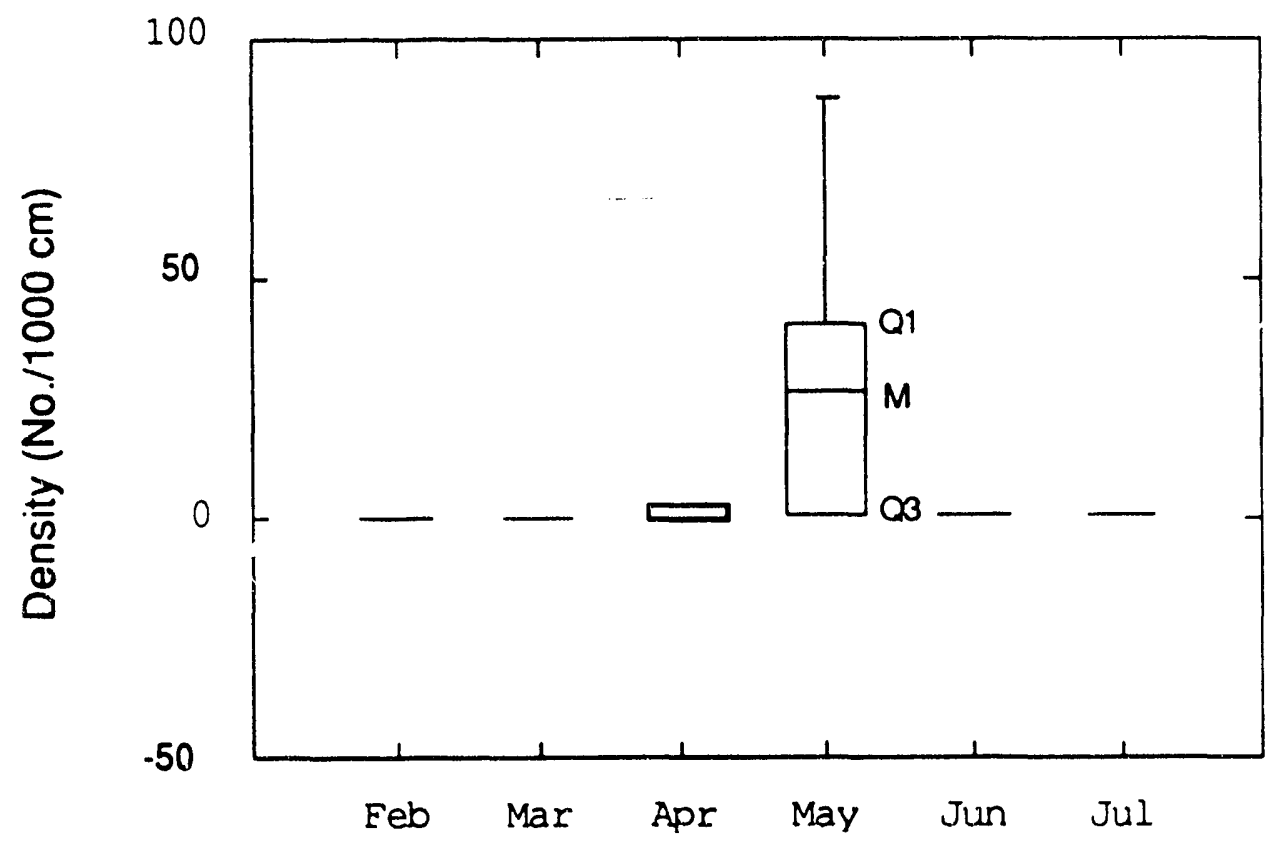

Month

Figure 5. Box plot showing monthly median (M), first quartile (Q2), third quartile (Q3), and range of striped bass ichthyoplankton densities (number/1000 cubic meters) during 1982 - 1985. 


\section{Percent withdrawal}

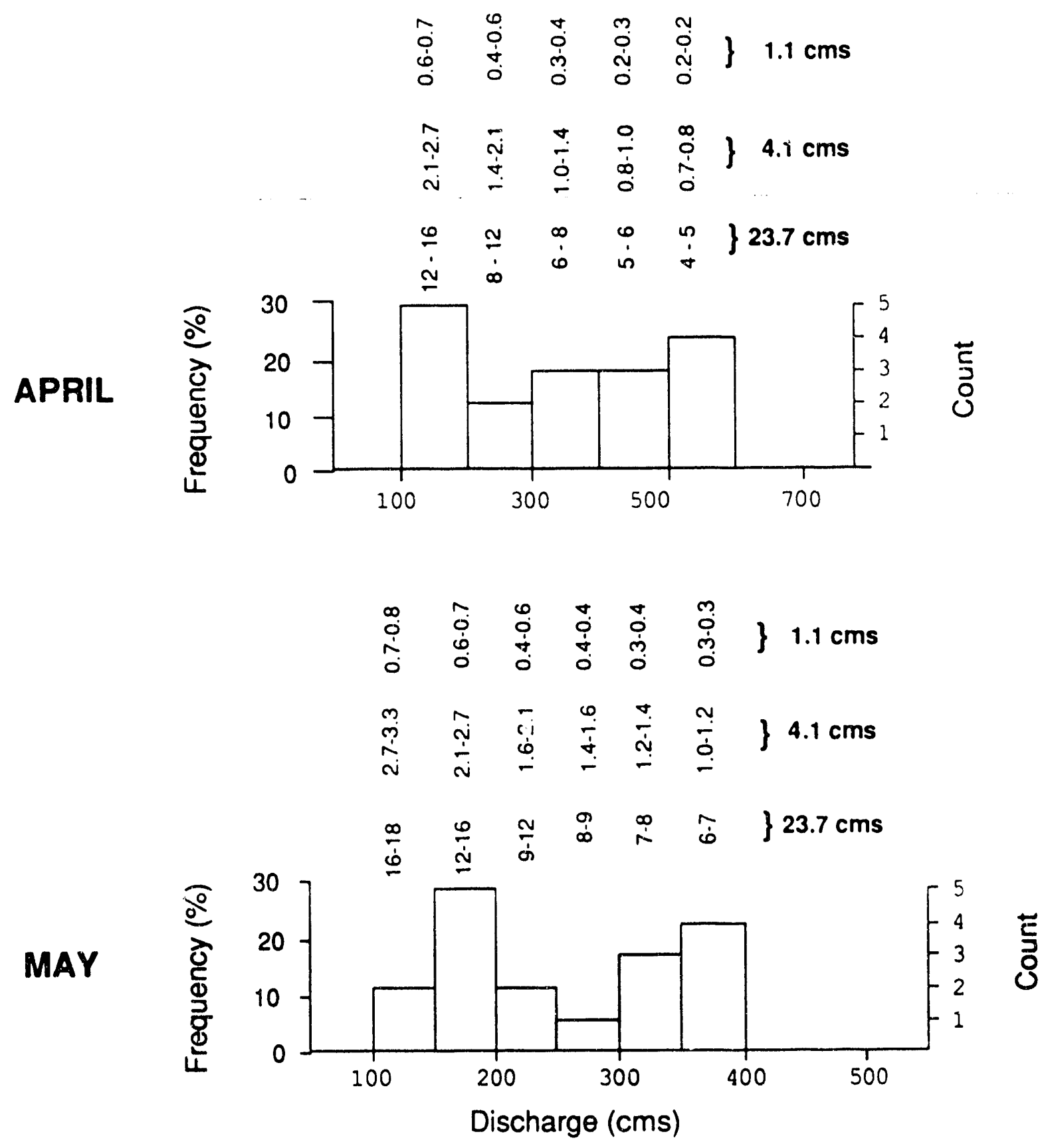

Figure 6. Frequency of occurrence of different Savannah River discharge levels during April and May 1973 1989 and the percentage of river water that would be withdrawn at each level assuming three rates of Savannah River water usage. 


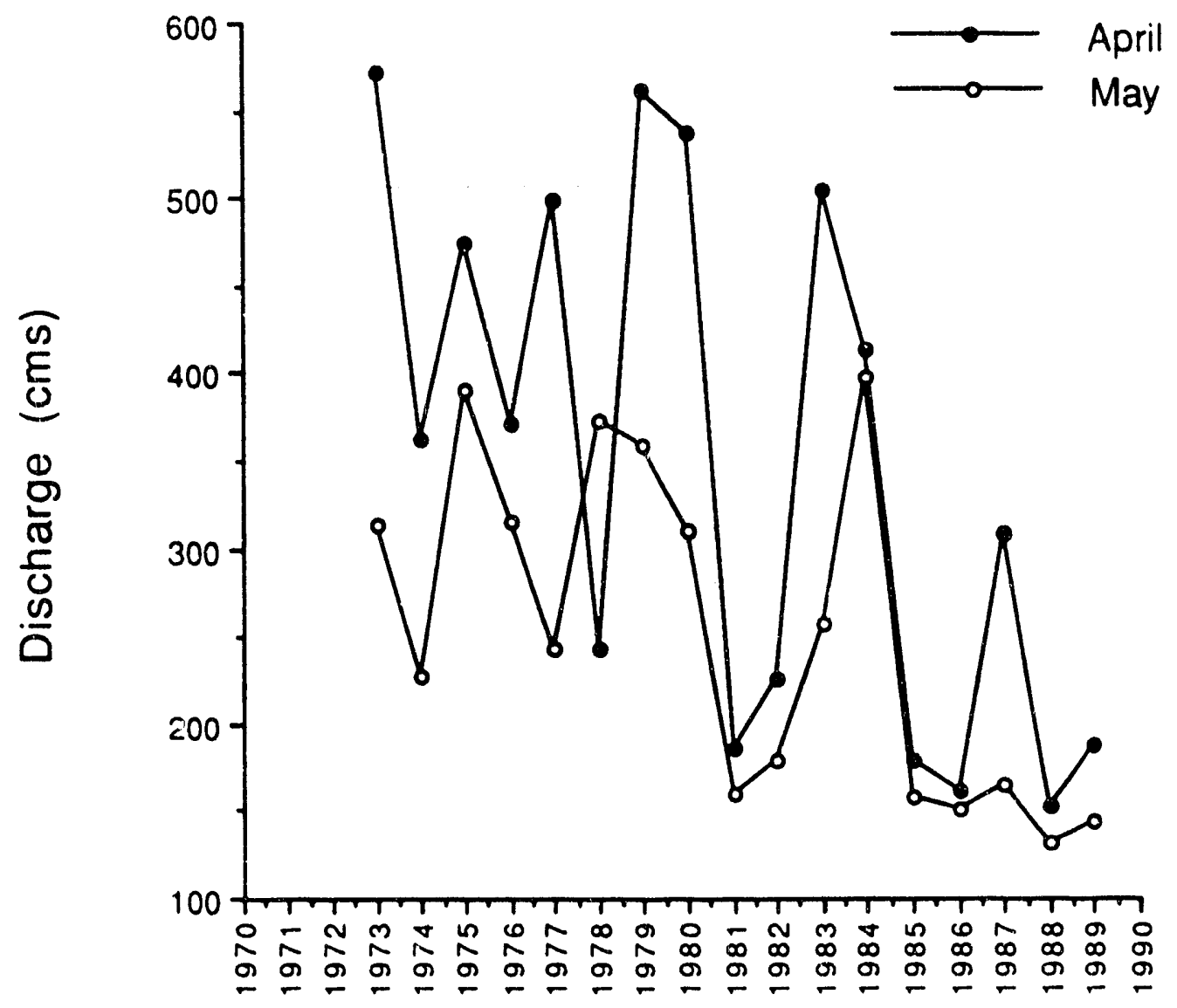

Figure 7. Average April and May discharge levels (cubic meters per second) in the Savannah River during 1973 - 1989. 
DATE FILMED $4 / 13 / 93$ 
